\title{
The Effects of Education on Enterprise Resource Planning Implementation Success and Perceived Organizational Performance
}

\author{
Yaşar Akça ${ }^{1}$, Şaban Esen ${ }^{1}$ \& Gökhan Özer ${ }^{2}$ \\ ${ }^{1}$ Faculty of Economics and Administrative Sciences, Bartin University, Bartin, Turkey \\ ${ }^{2}$ Management Faculty, Gebze Institute of Technology, Kocaeli, Turkey \\ Correspondence: Yaşar Akça, Faculty of Economics and Administrative Sciences, Bartın University, Bartın, \\ Turkey. Tel: 90-378-223-5339. E-mail: yakca@bartin.edu.tr
}

Received: March 3, 2013

doi:10.5539/ibr.v6n5p168

\author{
Accepted: April 2, 2013 \\ Online Published: April 17, 2013 \\ URL: http://dx.doi.org/10.5539/ibr.v6n5p168
}

\begin{abstract}
The aim of study is to define education activities which must be taken into consideration while implementing successfully the enterprise resource planning (ERP) software package system in the organization. To analyze the effect of education on the implementation success of ERP systems and organizational performance, the data obtained from 236 firms via mail survey were analyzed using regression. Findings obtained from analysis showed that (1) an increase in education activities increased the implementation success of ERP. (2) Education had a significant effect statistically on perceived organizational performance. (3) An increase in the implementation success of ERP increased the organizational performance significantly and (4) when the implementation success of ERP together with education were taken into consideration in explaining the perceived organizational performance; the variables such as the implementation success of ERP, were significantly meaningful.
\end{abstract}

Keywords: enterprise resource planning, education, implementation success, perceived organizational performance

\section{Introduction}

Information technology and information system terms are interchangeable. This terminology states information products and services based on computer. Products of computer hardware and software that ensure collection, processing, storing, analyzing, conveying and spreading of information based on computer. In order to ensure the processes of planning, control, coordination, decision making in enterprises, are called information system or information technologies (Laudon \& Laudon, 1991, p. 5).

Economies of today have based on computer, information, communication, technology and internet. So enterprises need intensive computer technology investments. Information technology ensures the effective combination of production factors and contributes to organizational performance (Torkzadeh, Koufteros \& Doll, 2005, p. 107).

One of the information technologies that attracts great attention and especially used in big enterprises is enterprise resource planning (ERP) software. This software is presents single information technology architecture to the organization. Including real time planning, production, customer management, resource management, quality control, distribution, sale, electronic trade, supply chain and integration (Siriginidi, 2000, p. 377), ERP software has been a new way for production of good and services by organizations. ERP is a solution for problems such as reducing costs, rapid implementation and high system quality. As it provides backbone and the function of digital neural system function, it is "indispensable" in the competition of enterprises (Sheu, Chae \& Yang, 2004, p. 362).

Many studies in the literature show that education of workers about their works increase their performances (Adams, Berner \& Rousse, 2004, p. 58; Gattiker, 2002, p. 103; Grossman \& Walsh, 2004, p. 40; Gyampah, 2004, p. 179). Surely, this increase in performance is reflected on the organizational performance (Thornhill, 2006, p. 693). On the other hand, education is one of the preconditions of building a successful ERP system (Bradford \& Florin, 2003, p. 215). The more complicated ERP software is the more education is needed.

In this study, we will analyze the implementation success of education given during ERP system setup besides its 
probability to have a positive effect on organizational performance. This research question is based on the observations that especially standard ERP software affects the working style in organizations and mostly changes process (Ahadi, 2004, p. 2; Siriginidi, 2000, p. 377). If the education given in order to make a successful setup changes working styles in the organization and work process, then it has to have an effect on performance free from the setup success.

\section{Literature Review and Theoretical Model Development}

Theoretical model that explains the education factor's effect on ERP information technology's implementation success and organizational performance is given in figure 1. Theoretical model has got three dimension; education, ERP implementation success and perceived organizational performance. Probability interactions among this three dimensions was demonstrated at model (see figure 1).

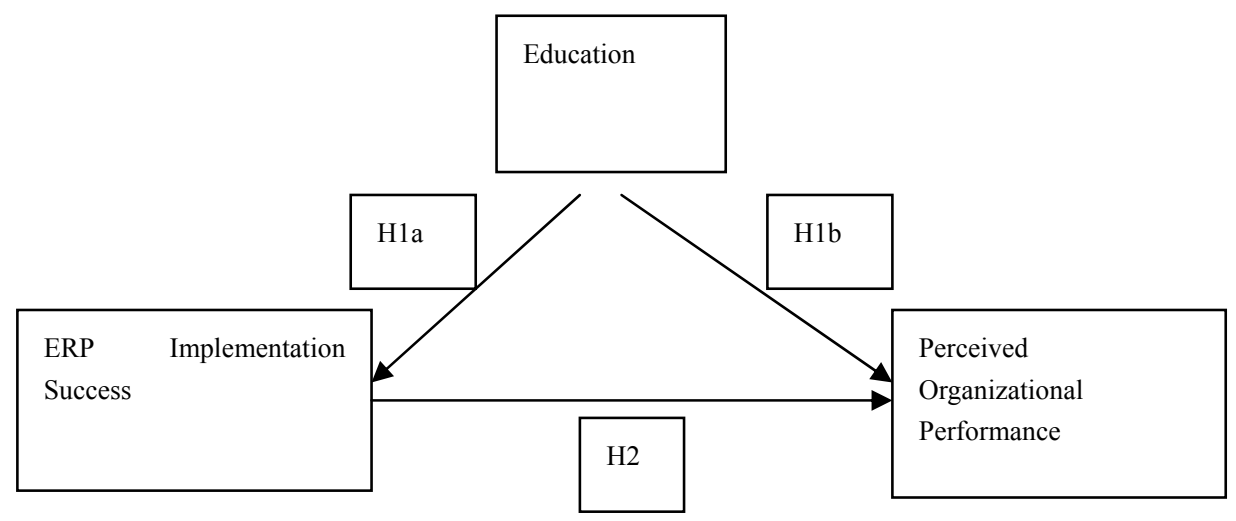

Figure 1. Theoretical model

\subsection{ERP Software Systems}

It is a set of integrated computer software systems that automates the flow of the entire functions of an organization (Wei \& Wang, 2004, p. 161). The use of same software system ensures automatization in the entire company and integrates data, processes, and implementation and distributes them. The basics of ERP; simple inventory management systems of 1960s were developed to material requirements planning systems (MRP) in 1970 and then production resources planning systems (MRPII) were developed. The fourth stage of these systems' evolution is enterprise resource planning.

ERP software systems is used in significant industries such as defense, aviation, metallurgy, finance, education, insurance, retailing, communication, building and production (Chung \& Snyder, 2000, p. 24). The reasons why companies prefer ERP systems are; weak performance, high costs, indifference to customers, complicated work processes, contradictions in systems, low information quality, old systems and insufficient support to development (Holland \& Light, 1999, p. 30-36). Companies that use ERP develops information production and transfer information effectively, so organizational decision making and planning develops, unnecessary procedures and paperwork decrease. It also integrates organization's work processes (Gyampah \& Salam, 2004, p. 734). Output costs, company expenses are minimized through better resource management; personnel saving increases production and productivity; financial performance gets better. Information communication is ensured by close collaboration between suppliers and customers. Timely distribution ratio increases, customer satisfaction and services gets better. It is also possible to make e-commerce implementations on the internet (Rashid, Hossain \& Patrick, 2002, p. 39).

Primary problems of companies during the process of KKP system setup: Transference of qualified technical staff that took ERP education causes slowdown of implementation process. It is an expensive information technology investment in short term. Services of consulting firms increase costs (Nah, Lau \& Kuang, 2001, p. 286). An intensive training is necessary in order to increase technical abilities of ERP users (Petroni \& Rizzi, 2001, p. 145). So, the education requires financial investment (Bingi, Sharma \& Golda, 2001, p. 434). Implementation costs increase in parallel with the increase in the number of modifications in the program made by the organization. (Bingi et al., 2001, p. 434). Chosen ERP system's harmonization with the organization's processes requires a certain time period. Personnels and managers resistance against organizational change as a result of the adaptation of technology is another issue to be discussed (Petroni \& Rizzi, 2001, p. 146). 


\subsection{Education}

Process of ensuring desired behavioral change of an individual is accepted to be the definition of education. Education that plays the basic role (Knol \& Stroeken, 2001, p. 233) in the acceptance and use of information technologies increases knowledge and profession level. This is why, it has been emphasized that education is one of the most significant factors that affect ERP systems adaptation success (Adams et al., 2004, p. 57). In other words, education is an integrated part of ERP implementation (Grossman \& Walsh, 2004, p. 40), and is one of the critical success factors (Gyampah, 2004, p. 179).

ERP education, it focuses on teaching the effective use of ERP system in daily activities by various user groups (Stratman \& Roth, 2002, p. 603), it means explaining the general logic of ERP system (Zhang, Lee, Zhang \& Banerjee, 2003, p. 241). The aim of ERP system is to ensure the flow of information and successful organizational performance. System can never be completely used without sufficient education. Users can understand their works relations to other functional areas in the company. Quantity and quality of user education increases the effective use of information systems (Gattiker, 2002, p. 103). Maximum use of information technology, efficiency and effectiveness can not be ensured if users aren't educated well. The most significant tool that affects behavior, performance, acceptance of technology, attitudes and beliefs is again education.

Abilities should be educated in ERP systems (Stratman \& Roth, 2002, p. 612). Because, users that have high performances are needed as ERP make inter-functional integration. An incorrect data entry from a module will have a reverse effect on the functions of other modules. As users learn how to carry out the works by ERP education, they naturally learn how to prevent problems; otherwise, expected data of the project can not be obtained and ERP system has no effect. Education will make users a part of the system (Adams et al., 2004, p. 58); it will ensure learning and use of ERP system and will let users have interaction with ERP (Gyampah \& Salam, 2004, p. 735). Workers can use the system more consciously and more effectively.

Information given to users decreases indefiniteness and ends fear. Education is necessary in order to overcome the reluctance of managers and workers about ERP system (Gattiker, 2002, p. 103; Perez, Sanchez, Carnicer \& Jimenez, 2004, p. 285). It helps creating positive relations against the system. Davis (1983, p. 103) states that a good education can help users overcome their fears and hesitations. Education should be given before the set up of the system (Adams et al., 2004, p. 57). But ERP education shouldn't be considered as a time issue. During radical process changes and system updating resulting from ERP implementations, managers and workers should be educated for a sufficient amount of time (Stratman \& Roth, 2002, p. 612).

ERP systems require continuous education. ERP education planning should be done at the beginning of the project. In the first phase of education, the system is identified (Aladwani, 2001, p. 269) and its benefits are explained. Systems necessity and suitability for the organization are expressed. Tools, terminology, new techniques are taught, new responsibilities are given. When the system is applied, its working system is explained (Aladwani, 2001, p. 270). System's general structure is understood and user's place in the system is presented. Education shows why the change is necessary. Education is a significant opportunity as it ensures users get used to the change presented by the system (Aladwani, 2001, p. 271).

Basic issues of ERP education are: Technical content about the professions of users (Adams et al., 2004, p. 57), interrelations of the modules in the package (Gattiker, 2002, p. 103), analysis of business process controls, use of system, data analysis, abilities of the system and its benefits for users (O'Leary, 2002, p. 123; Zhang et al., 2003, p. 241). Finally, the education should be combined with performance evaluation. As orientation is significant in ERP technologies, education should be given in the company, because education process is expensive and takes much time. ERP is a big part of implementation budget (Gyampah, 2004, p. 179). It can sometimes cost as much as the system. Sufficient time and resources should be given to the workers who are being educated. Education programs can be developed in the company (Kumar, Maheshwari \& Kumar, 2003, p. 801). After the education of a core user group by ERP seller, they can convey what they learn to other user groups.

Failure in education causes implementation problems (Umble \& Umble, 2002, p. 27). To say that an education is successful, workers should be able to solve problems that they face in the system after education. Education is important in order to ensure an efficient use of the system, to have benefits for the company, to overcome difficulties in implementation, timeout and expanses.

Zhang et al. (2003, p. 241), that test the hypothesis defending that education has a positive effect on ERP implementation success stated that the hypothesis is supported through empirical data gathered from 47 companies (Zhang et al., 2003, p. 243). At the same time, education is accepted to be the key process in supporting of organizational development. Zviran and Erlich (2003, p. 82) stated that education of workers will contribute to organizational performance. Kanji (1996, p. 5), said that: "Workers should know what to do and 
how to do it in order to increase the performance of an organization" and emphasized the importance of education. Birley and Westhead (1990, p. 540), tested on 249 companies the hypothesis that education has a positive relation with growth and high performance and they reported that there was a positive relation at $\% 1$ meaningfulness level (Birley \& Westhead, 1990, p. 544). Thornhill (2006, p. 693), made a study on 845 Canadian countries that employ 500 or less workers; he tested the hypothesis that education investment level will have a positive effect on company performance. According to his study, there is a positive and significant relation (Thornhill, 2006, p. 697).

In the light of this information, hypothesis to be tested about the role of education variable are:

$H_{1 a}$ : Education has a positive effect on ERP implementation success.

$H_{l b}$ : Education has a positive effect on perceived organizational performance.

\subsection{ERP Implementation Success}

Companies that adapt ERP systems need to evaluate performance. It is difficult to evaluate contributions of information system to performance if costs and benefits can not be evaluated (Zhang et al., 2003, p. 239). It is also difficult to evaluate success in terms of customers, suppliers, investments of organizations that adapt ERP. On the other hand, although companies that use ERP systems are increasing, researches on these companies (Özer, Yücel \& Yılmaz, 2003, p. 78) show that most of them have no systematic methodology in evaluating ERP systems' success and effectiveness.

Success of the information system: It means benefits of information system (Ashill \& Jobber, 1999, p. 519). Torkzadeh and Doll (1999, p. 327) evaluated the success of information technology in terms of its effects on last user's work. Some ways such as benefit-cost analysis, system use, benefit analysis, performance increase in decision making process were suggested by these researchers (Thong, Yap \& Raman, 1997, p. 257). DeLone and McLean (1992, p. 80), stated that there is not a consensus in the evaluation of information systems and determined six dimensions in evaluating the success of information systems. These dimensions are: System quality, information quality, use, user satisfaction, personal effect and organizational effect.

Success of ERP system means the goals of the system. The system's success means the best outputs that can be obtained with ERP system (Markus, Axline, Petrie \& Tanis, 2000, p. 247). Improving organizational abilities by using ERP system means reducing stocks, improving decision support and completing the determined budget in time. If a company stops using ERP system can not meet the goals of company, this means failure (Markus et al., 2000, p. 247). As success and failure is multi dimensional. ERP success is considered to be a moving goal (Liang \& Xue, 2004, p. 401). This is why, Markus et al. (2000, p. 246) took three different time period into consideration and evaluated success of organizations that adapted ERP system;

1) Project phase of ERP system: Comparison of project budget and costs, planning time and completion time.

2) The phase of starting active use: Stock level, process cycle time, labor cost, average time spent with customers and suppliers.

3) The phase when companies start benefiting from ERP system: Decrease in information technology processing costs and stock costs, improving in company results, ease in making managerial decisions, ease in additional technological innovations' application. As a result, ERP success is the change of process in time (Liang \& Xue, 2004, p. 401).

This hypothesis is formed in the light of this evaluation:

\section{$\mathrm{H}_{2}$ : ERP implementation success positively affects the perceived organizational performance.}

\subsection{Perceived Organizational Performance}

Performance is improving organization's efficiency by the system (Palvia, Sharma \& Conrath, 2001, p. 249). Fuentes, Saez and Montes (2004, p. 427), explained organization performance as economic goals of a company. Organization performance evaluates the effect of information system on business performance (Zviran \& Erlich, 2003:82). Information system affects the success of a company in terms of saving time, formalization and restructuring work processes (Thong, Yap \& Raman, 1996, p. 255).

Measuring company performance can be analyzed in three dimensions; financial performance, market performance and economic performance.

Market performance, is the outer performance it means a company's success in a market. Increases in sales, market share, level of customer satisfaction are some factors that show market performance (Westerberg, Singh \& Hackner, 1997, p. 252). It is also possible to evaluate market performance by analyzing product quality, new 
product presentation, comparison with rivals' performances (Bergeron, Raymond \& Rivard, 2001, p. 134).

Financial performance means operating effectiveness of a company. It explains how a company transforms market demands into profitable products. Duty of a production is to convert inputs such as raw material and labor into outputs for market. Indicators of financial performance are profitability and productivity (Westerberg et al., 1997, p. 252). So, organizational performance can be analyzed through indicators of costs, competitiveness, pure profit and controlling activity costs (Strandholm, Kumar \& Subramanian, 2004, p. 63). Evaluation of performance in most information system studies are based on financial ratios such as proceeds of investment, activities, increase in income and sales, earnings per stock (Bergeron et al., 2001, p. 131-134). So, evaluations focus on the economic dimension of performance.

The process of evaluating organizational performance is according to the perceptions before and after the use of ERP system. Accountancy and marketing departments managers were asked about the performance of organization in terms of profitability, increase in sales, change in stock level, market share, costs, financial budget goals, organization's performance in the satisfaction of customers. It was understood that ERP systems have positive effects on companies' financial performance (Kearns \& Lederer, 2004, p. 906; King, 2005, p. 83). Results in Reck's (2004, p. 107) study supports that ERP system application contributes to increasing company's financial performance. Poston and Grabski (2001, p. 286), reported that ERP system application decrease the number of workers and significant betterments occur in the costs of sold products.

\section{Research Method}

Creation of scales will be explained in this section. Data collection method will be described. Factor analysis, reliability and validity hypothesis tests results will be explained. Suggestions will be made for the constraints of the study and future studies.

\subsection{Scales of Variables}

Questions in the research that are asked in order to analyze the effects between variables were adapted from the scales from the literature whose validity and reliability was tested. Survey questions were evaluated with five likert type scale including answers ranging from 1 (absolutely don't agree) and 5 (absolutely agree).

Education is the first variable that was analyzed. Survey questions that evaluate ERP education were adapted form Gyampah and Salam's (2004, p. 737) article. The first of the survey questions that evaluate ERP application success was taken from Stratman and Roth's (2002, p. 609), other three questions were taken from Hong and Kim's (2002, p. 38) articles. The first two questions for perceived organizational performance were taken from Deloitte Consultancy (1999, p. 15), other questions included scales developed by Ramamurthy and Premkumar (1995, p. 349) and Stenbeck (1998, p. 2).

\subsection{Data Collection}

The universe of the research was ERP using companies in Turkey. In order to ensure the sampling reflect universe in an optimum level, reference customers mentioned in the internet pages of companies that produce, sell and give consultancy services about ERP setup. Prepared survey form was firstly created by face to face meetings with ERP using 40 companies' accounting and data process departments managers. After evaluating these managers suggestions on these questions and pre-test results, some questions were reshaped.

Surveys were posted on 610 ERP using companies and answers were taken from 236 companies. Survey participation rate is approximately $\% 40 . \% 95$ of the participators was graduated from university. Individuals who answered the questions were mostly accounting officers (\%59), ERP specialist officers (\%23), product managers (\%8), general manager/assistant and coordinator (\%6) and marketing managers (\%4). In terms of sale revenue, $\% 70$ of participator companies and the number of workers almost half of the companies (\%46) were big enterprises. $\% 35$ of companies has been in the industries at least for 16 years. $\% 32$ of the companies have been in metal sector $\% 18$ petrochemistry, $\% 13$ in textile sector, $\% 12$ in services sector, $\% 10$ have been in food sector. \%40 of ERP system users that participated in the survey had 1-3 years work experience; \%21 had 4-6 years work experience; $\% 23$ had 7-11 years work experience and \%16 had more than 12 years of work experience.

\subsection{Factor Analysis, Validity and Reliability}

As all of the scales that are used were tested in previous researches, they are theoretically and experimentally strong. But still, questions that evaluate variables should be evaluated in terms of validity and reliability. This is why, SPSS statistical analysis program was used and intentional factor analysis was made with variance maximization method. 
Kaiser-Meyer-Olkin (KMO) sampling sufficiency criterion and Barlett test were used for testing homogeneity of variables and convenience of factor analysis. KMO is an index that is used for measuring sufficiency of sampling size for factor analysis by comparing the size of partial correlation coefficient and observed correlation coefficient size. KMO 0,904 that was obtained through analysis shows that variables are homogenous and there is a relation between variables (Mitchell, 1994, p. 6). Barlett test results (Barlett test value 3327,705 and p<0, 01) obviously show that there is a relation between variables. According to ERP results, 20 questions were loaded to 4 factors and $\% 65.68$ of total variance was explained.

Cronbach $\alpha$ coefficient was used in order to evaluate internal consistency and reliability of the used variables. Cronbach $\alpha$ tests internal consistency and reliability of a scale when differences are evaluated (Cronbach, 2004, p. 4). As can be seen from Table 1, Cronbach $\alpha$ value are over 0,70 which is the critical value. These values show that reliability is satisfying (Choe, 1998, p. 189). Cronbach $\alpha$ value of variables are higher than the correlation value between variables, so it can be said that selection validity is obtained.

Table 1. Factor loads of variables and cronbach $\alpha$ value

\begin{tabular}{|c|c|c|c|}
\hline Factors and Scales & Factor 1 & Factor 2 & Factor 3 \\
\hline \multicolumn{4}{|l|}{ 1. Education (Cronbach $\alpha: 0.886$ ) } \\
\hline Our company gave an intensive Education to the employee for ERP system. & 0.780 & & \\
\hline Our company gives importance to the issue that employee have knowledge about ERP system. & 0.732 & & \\
\hline After education program rather advanced & 0.777 & & \\
\hline my understanding level of ERP system & 0.782 & & \\
\hline Education about the new system gives me confidence. & 0.771 & & \\
\hline Education is long and detailed enough. & 0.678 & & \\
\hline \multicolumn{4}{|l|}{ Educators are intellectual and they help me understand the system. } \\
\hline \multicolumn{4}{|l|}{ 2. KKP Implementation Success (Cronbach $\alpha: 0.827$ ) } \\
\hline ERP system improved the efficiency of distribution function. & & 0.542 & \\
\hline Cost of ERP system was significantly over the estimated budget. & & 0.601 & \\
\hline ERP system performance meets the expectations. & & 0.836 & \\
\hline ERP system is successful & & 0.800 & \\
\hline \multicolumn{4}{|l|}{ 3. Perceived Organizational Performance (Cronbach $\alpha: 0.931$ ) } \\
\hline ERP system increased sales. & & & 0.835 \\
\hline ERP system increased profit. & & & 0.783 \\
\hline Stock level decreased. & & & 0.543 \\
\hline Market share increased. & & & 0.864 \\
\hline There had been contributions to marketing diversity. & & & 0.859 \\
\hline There had been contributions to decreasing marketing costs. & & & 0.712 \\
\hline There had been contributions to reaching budget goals. & & & 0.522 \\
\hline There had been contributions to improving sale process. & & & 0.594 \\
\hline There had been contributions to increasing the number of customers. & & & 0.788 \\
\hline There had been contributions to increasing customer satisfaction. & & & 0.560 \\
\hline
\end{tabular}

In Table 2, average, standard deviation and correlation analysis of variables are presented. When correlation results between variables are analyzed, it is seen that all relations are statistically meaningful and positive.

Table 2. Descriptive statistics and correlations about variables

\begin{tabular}{lllllll}
\hline & & Mean & Standard Variation & $\mathbf{1}$ & $\mathbf{2}$ & $\mathbf{3}$ \\
\hline 1 & Education & 3.68 & 0,85 & 1 & & \\
2 & ERP implementation Success & 3,66 & 0.72 &, $549^{*}$ & 1 & \\
3 & Perceived Organizational Performance & 3,15 & 0,73 &, $467 *$ &, $598^{*}$ & 1 \\
\hline
\end{tabular}

Note: *Correlation, meaningful at 0.01 level.

\subsection{Testing Hypothesis}

Four regression equations were made in order to test the hypothesis. Goal of the first equation was to evaluate education factor's effect on ERP implementation success. In the second regression equation, the goal was to research the effect of education on perceived organizational performance. Regression equation number 3 , through which the effect of ERP implementation success on perceived organizational performance was 
researched. In the last equation, the goal was to test the variations of education and ERP implementation on perceived organizational performance.

$$
\begin{gathered}
U B=\beta_{0}+\beta_{1} * E G+e \\
O P=\beta_{0}+\beta_{1} * E G+e \\
O P=\beta_{0}+\beta_{1} * U B+e \\
O P=\beta_{0}+\beta_{1} * E G+\beta_{2} * U B+e
\end{gathered}
$$

(UB=KKP Implementation Success, $\mathrm{EG}=$ Education, $\mathrm{OP}=$ Perceived Organizational Performance, $\mathrm{e}=$ mistake)

Regression equation number 1 through which the effect of education on ERP implementation success was researched, was statistically meaningful $(\mathrm{F}=148.893 ; \mathrm{p}<0.01)$. It can be seen that education $(\beta=0.633, \mathrm{p}<0.01)$ had a positive effect on ERP implementation success and this effect was statistically meaningful. In other words, the more education activities increase, the more ERP implementation success increases. Education has an explanatory power by $3.68 \%$ on implementation success. This result shows that $\mathrm{H}_{1 \mathrm{a}}$ hypothesis was supported. The result of analyses display that the effectiveness of education has partial mediation effect (Note 1) on the ERP implementation success. Regression equation number 2, through which the effect of education on perceived organizational performance was researched, was found to be statistically meaningful $(\mathrm{F}=22.958, \mathrm{p}<0.01)$. It can be seen that education $(\beta=0.520, p<0.01)$ had a positive effect on perceived organizational and this effect was statistically meaningful. These results show that $\mathrm{H}_{1 \mathrm{~b}}$ hypothesis was supported. Regression equation number 3 , through which the effect of ERP implementation success on perceived organizational performance was researched, was found to be statistically meaningful $(\mathrm{F}=139.737, \mathrm{p}<0.01)$. Regression parameters show that perceived organizational performance increases in parallel with the increase in ERP implementation success ( $\beta=$ $0.611, \mathrm{p}<0.01)$. Parameter is high when compared to positive and other variables. This finding shows that ERP

\begin{tabular}{|c|c|c|c|c|c|c|c|c|}
\hline \multirow[b]{3}{*}{$\begin{array}{l}\text { Independent } \\
\text { Variables }\end{array}$} & \multirow{2}{*}{\multicolumn{2}{|c|}{$\begin{array}{l}\text { Regression Number } 1 \\
\text { ERP implementation } \\
\text { success }\end{array}$}} & \multirow{2}{*}{\multicolumn{2}{|c|}{$\begin{array}{l}\text { Regression Number } 2 \\
\text { Perceived Organizational } \\
\text { Performance }\end{array}$}} & \multicolumn{2}{|c|}{ Regression Number 3} & \multicolumn{2}{|c|}{ Regression Number 4} \\
\hline & & & & & $\begin{array}{l}\text { Perceived } \\
\text { Performan }\end{array}$ & Organizational & $\begin{array}{l}\text { Perceived } \\
\text { Performance }\end{array}$ & Organizational \\
\hline & $\beta$ & $\mathrm{t}$ & $\beta$ & $\mathrm{t}$ & $\beta$ & $\mathrm{t}$ & $\beta$ & $\mathrm{t}$ \\
\hline Education & 0.633 & $12.202 *$ & 0.520 & $7,743^{*}$ & - & - & 0.154 & $2.623^{*}$ \\
\hline $\begin{array}{l}\text { ERP implementation } \\
\text { success }\end{array}$ & - & - & - & - & 0.611 & $11.821 *$ & 0.627 & $10.649 *$ \\
\hline $\mathrm{F}$ & 148.893 & & 22,958 & & 139.737 & & 129.765 & \\
\hline $\mathrm{R}^{2}$ & 0.400 & & 0,291 & & 0.374 & & 0.539 & \\
\hline Corrected $\mathrm{R}^{2}$ & 0.398 & & 0,278 & & 0.371 & & 0.535 & \\
\hline
\end{tabular}
implementation success has the highest effect on perceived organizational performance. As a result, $\mathrm{H}_{2}$ hypothesis was supported.

Table 3. Regression analysis results

Note: *Meaningful at 0.01 level.

Effect of education and ERP implementation success on perceived organizational performance was researched with regression equation number 4 which was found to be statistically meaningful $(\mathrm{F}=129.765, \mathrm{p}<0.01)$. According to regression parameters, education $(\beta=0.154, \mathrm{p}<0.01)$ and ERP implementation success $(\beta=0.627$, $\mathrm{p}<0.01)$ affect perceived organizational performance positively.

Table 4. The results of hypothesis

\begin{tabular}{lll}
\hline Hypothesis No. & Hypothesis & Result \\
\hline $\mathbf{H}_{1 \mathrm{a}}:$ & Education affects ERP implementation success positively & Supported \\
$\mathbf{H}_{1 \mathrm{~b}}:$ & Education affects ERP perceived organizational performance positively & Supported \\
$\mathbf{H}_{2}:$ & ERP implementation success affects perceived organizational performance positively KKP & Supported \\
\hline
\end{tabular}

\subsection{Constraints of the Study and Suggestions for Future Studies}

This study has some constraints; first of these constraints is the size of sampling by participators. It was impossible determine the entire universe in this research. There was no institution that reports the companies that set up and use ERP systems. Reference customers mentioned in the internet pages of companies that ERP setup. 
Surveys were posted to 610 ERP using companies and answers were taken from 236 of them. Size of the sampling prevents the generalization of research results for ERP using companies.

The second constraint is general reluctance. Some of the companies to who surveys were sent them back by giving some excuses such as they had just set up the system or they were still setting it, the set up modules were limited (one or two modules) or it was early to make comments, they didn't have time to answer the survey. Besides these, the study was -in a way- a starting point for the adaptation of information technologies such as ERP system to organizations in Turkey. A new perspective can be created for organizations that produce, sell and implement ERP software for potential ERP system using companies managers.

It is possible to make some suggestions for future studies. These suggestions can be divided into 4 groups: (1) Focus can be on complexity dimensions such as the number of modules integrated at researches (2) Work implementations of ERP systems and their effects on organizational structure can be researched (3) ERP systems' effects on information quality can be analyzed (4) A bigger sampling group can be used by extending the independent variables of studies.

Detailed studies on this issue can create a chance to find solution to general problem of seeing ERP systems as disadvantages. Shortly, contribution of academic literature in ERP systems development is a well structured theory (Holland \& Light, 2001, p. 43).

\section{Conclusion}

Goal of our study was to identify the education factor that should be taken into consideration in order to successfully set up organizational resource planning software and to analyze the effects of this factor on ERP system implementation success and organizational performance. In order to reach this goal, data gathered from 236 companies through surveys were analyzed by using regression.

The first finding of the analysis shows that education positively and meaningfully affects both ERP implementation success and perceived organizational performance. Results of this study that represents education's effects on ERP implementation success and perceived organizational performance support the findings of most of the study in literature (Bradford \& Florin, 2003, p. 215; Kearns \& Lederer, 2004, p. 906; King, 2005, p. 83; Poston \& Grabski, 2001, p. 286; Reck, 2004, p. 107; Thornhill, 2006, p. 697; Zhang et al., 2003, p. 243; Zviran \& Erlich, 2003, p. 82). The second finding of the analysis shows that increase in ERP implementation success increases organizational performance in a statistically meaningful way. This finding that shows the positive effect of organizational resource planning implementation success on perceived organizational performance as a result of a general acceptance which defends that innovation contributes to company performance supports the statements of Hult, Hurley and Knight (2004, p. 429). This results indicated that the contribution of this study to the existing knowledge.

When all of the analyses were evaluated, it was seen that ERP implementation success affects perceived organizational performance the most. Education affects organizational performance directly or indirectly through implementation success besides affecting ERP implementation success. When ERP implementation success and its effects on organizational performance are evaluated in terms of managerial dimension, it can be said that firstly users' education should be taken into consideration in marketing activities of ERP systems and in the ideas of companies that want to set up this system are put into practice. While ERP sellers convince companies about setting up this system, they should especially emphasize that education is easy and inexpensive. Company managers, on the other hand, should know that maximum performance can be reached through educating computer users.

With ERP education, effective and efficient use of information technology in a company will be possible and bigger organizational performance will be ensured. Because men is the user of the information gathered by the system and again men is the one who makes data entry into the system. Amount and qualification of the education determines the success of the system. Acceptance, adoption of the system by users, their attitudes and beliefs can only be affected by education. System users can only gain abilities that are needed by the system through education. ERP system performance is in direct relation with users' performance. Interaction with the system will be possible with the knowledge about ERP package program and users will become a part of the system. Overcoming the stress, negative feelings, worries, and fears is possible only with education. ERP educations that include entire users should be continuous.

Use of ERP systems is a must in order to cope with the fast changes in business environment. Enterprise workers can cope with these changes with the help of ERP education. Use of ERP packages ensures support to decision making processes and making right decisions. Pressure caused by commercial rivals can be prevented by ERP. 
Flexibility against changing market conditions is earned (Poston \& Grabski, 2001, p. 272-273). Communication and coordination will increase, trading volume, supply/demand will increase. Demand estimation correctness will increase. Better resource management will be possible; accordingly, enterprise and purchase expenses will decrease besides progresses in business processes, production and productivity.

When institutional performance increase is taken into consideration, the most significant variable is surely implementation success. Among the variables that we dealt with until now, the one that affects institutional performance the most is ERP implementation success. This is why, it can be said that corporations that implement ERP systems successfully will significantly increase their organizational performances.

\section{References}

Adams, B., Berner, E., \& Rousse, J. (2004). Applying Strategies to Overcome User Resistance in a Group of Clinical Managers to a Business Software Application: A Case Study. Journal of Organizational and End User Computing, 16(4), 55-64. http://dx.doi.org/10.4018/joeuc.2004100104

Ahadi, H. (2004). An Examination of The Role of Organizational Enablers in Business Process Reengineering and The Impact of Information Technology. Information Resources Management Journal, 17(4), 1-19. http://dx.doi.org/10.4018/irmj.2004100101

Aladwani, A. M. (2013). Change Management Strategies for Successful ERP İmplementation. Business Process Management Journal, 7(3), 266-275. http://dx.doi.org/10.1108/14637150110392764

Ashill, N., \& Jobber, D. (2013). The Impact of Environmental Uncertainty Perceptions, Decision Maker Characteristics and Work Environment Characteristics on The Perceived Usefulness of Marketing Information Systems (MkIS): A Conceptual Framework. Journal of Marketing Management, 15, 519-540. http://dx.doi.org/10.1362/026725799785045815

Baron, R. M., \& Kenny, D. A. (1986). The Moderator-Mediator Valiable Distiction in Social Psychological Research. Journal of Personality and Social Psychology, 51(6), 1173-1182. http://dx.doi.org/10.1037/0022-3514.51.6.1173

Bergeron, F., Raymond, L., \& Rivard, S. (2001). Fit in Strategic Information Technology Management Research: An Empirical Comparison of Perspectives. Omega, 29, 125-142. http://dx.doi.org/10.1016/S0305-0483(00)00034-7

Bingi, P., Sharma, M., \& Golda, J. (2001). Enterprise Systems Integration. In Myerson, J. (Ed.), Critical Issues Affecting an ERP Implementation (pp. 425-438). Florida, Amerika Birleşik Devletleri: Auerbach Publishers Inc.

Birley, S., \& Westhead, P. (1990). Growth and Performance Contrasts Between Types of Small Firms. Strategic Management Journal, 11(7), 535-557. http://dx.doi.org/10.1002/smj.4250110705

Bradford, M., \& Florin, J. (2003). Examining The Role of Innovation Diffusion Factors on The Implementation Success of Enterprise Resource Planning Systems. International Journal of Accounting Information Systems, 4, 205-225. http://dx.doi.org/10.1016/S1467-0895(03)00026-5

Choe, J. M. (1998). The Effects of User Participation on the Design of Accounting Information Systems. Information \& Management, 34, 185-198. http://dx.doi.org/10.1016/S0378-7206(98)00055-X

Chung, S. H., \& Snyder, C. A. (2000). ERP Adaption: A Technological Evoluation Approach. International Journal of Agile Management Systems, 2(1), 24-32. http://dx.doi.org/10.1108/14654650010312570

Cronbach, L. J. (2004). My Current Thoughts on Coefficient Alpha and Successor Procedures (University of California No. CSE Report 643).

Davis, W. S. (1983). Systems Analysis and Design, A Structured Approach. Massachusetts, Amerika Birleşik Devletleri: Addison Wesley Publishing Company.

Deloitte Consulting. (1999). ERP's Second Wave: Maximizing The Value of ERP-Enabled Processes.

Delone, W. H., \& Mclean, E. (1992). Information Systems Success: The Quest for The Dependent Variable. Information System Research, 3(1), 60-95. http://dx.doi.org/10.1287/isre.3.1.60

Fuentes, M. M., Saez, C. A. A., \& Montes, F. J. L. (2004). The Impact of Environmental Characteristics on TQM $\begin{array}{llll}\text { Principles and Organizational Performance. } & \text { Omega, 32(6), }\end{array}$ http://dx.doi.org/10.1016/j.omega.2004.02.005

Gattiker, T. F. (2002). Anatomy of an ERP Implementation Gone Awry. Production and Inventory Management 
Journal, 43(3/4), 96-105.

Grossman, T., \& Walsh, J. (2004). Avoiding the Pitfalls of ERP System Implementation. Information Systems Management, 21(2), 38-42. http://dx.doi.org/10.1201/1078/44118.21.2.20040301/80420.6

Gyampah, K. A. (2004). ERP Implementation Factors A Comparison of Managerial and End User Perspectives. Business Process Management Journal, 10(2), 171-183. http://dx.doi.org/10.1108/14637150410530244

Gyampah, K. A., \& Salam, A. F. (2004). An Extension of The Technology Acceptance Model in an ERP Implementation Environment. Information \& Management, 41, 731-745. http://dx.doi.org/10.1016/j.im.2003.08.010

Holland, C. P., \& Light, B. (1999). A Critical Success Factors Model for ERP Implementation. IEEE Software Review, 16(3), 30-36. http://dx.doi.org/10.1109/52.765784

Holland, C. P., \& Light, B. (2001). A Stage Maturity Model for Enterprise Resource Planning Systems Use. Database for Advances in Information Systems, 32(2), 34-45. http://dx.doi.org/10.1145/506732.506737

Hong, K. K., \& Kim, Y. G. (2002). The Critical Success Factors for ERP Implementation: An Organizational Fit Perspective. Information \& Management, 40, 25-40. http://dx.doi.org/10.1016/S0378-7206(01)00134-3

Hult, G. T. M., Hurley, R. F., \& Knight, G. A. (2004). Innovativeness: Its Antecedents and Impact on Business $\begin{array}{llll}\text { Performance. } \quad \text { Industrial } & \text { Marketing }\end{array}$ http://dx.doi.org/10.1016/j.indmarman.2003.08.015

Kanji, G. K. (1996). Can Total Quality Management Help Innovation? Total Quality Management, 7(1), 3-9. http://dx.doi.org/10.1080/09544129650035007

Kearns, G. S., \& Lederer, A. L. (2004). The Impact of Industry Contextual Factors on IT Focus and The Use of IT for Competitive Advantage. Information \& Management, 41, 899-919. http://dx.doi.org/10.1016/j.im.2003.08.018

King, W. R. (2005). Ensuring ERP Implementation Success. Information Systems Management, 22(3), 83-84. http://dx.doi.org/10.1201/1078/45317.22.3.20050601/88749.11

Knol, W. H. C., \& Stroeken, J. H. M. (2001). The Diffusion and Adaption of Information Technology in Small and Medium Sized Enterprises Through IT Scenarios. Technology Anaysis \& Strategic Management, 13(2), 227-246. http://dx.doi.org/10.1080/09537320123815

Kumar, V., Maheshwari, B., \& Kumar, U. (2003). An Investigation of Critical Management Issues in ERP Implementation: Emperical Evidence From Canadian Organizations. Technovation, 23, 793-807. http://dx.doi.org/10.1016/S0166-4972(02)00015-9

Laudon, K. C., \& Laudon, J. P. (1991). Business Information Systems: A Problem Solving Approach. Orlando, Amerika Birleşik Devletleri: The Dryden Pres.

Liang, H., \& Xue, Y. (2004). Coping with ERP Related Contextual Issues in SMEs: A Vendor's Perspective. Journal of Strategic Information Systems, 13, 399-415. http://dx.doi.org/10.1016/j.jsis.2004.11.006

Markus, M. L., Axline, S., Petrie, D., \& Tanis, C. (2000). Learning From Adopters' Experiences with ERP: Problems Encountered and Success Achieved. Journal of Information Technology, 15, 245-265. http://dx.doi.org/10.1080/02683960010008944

Mitchell, V. W. (1994). How to Identify Psychographic Segments: Part1. Marketing Intelligence and Planning, 12(7), 4-10. http://dx.doi.org/10.1108/EUM0000000003905

Nah, F. F. H., Lau, J. L. S., \& Kuang, J. (2001). Critical Factors For Successful Implementation of Enterprise $\begin{array}{lllll}\text { Systems. Business Process } & \text { Management Journal, } & \text { 7(3), }\end{array}$ http://dx.doi.org/10.1108/14637150110392782

O’Leary, D. E. (2002). Discussion of Information System Assurance for Enterprise Resource Planning Systems: Unique Risk Considerations. Journal of Information Systems, 16, 115-126. http://dx.doi.org/10.2308/jis.2002.16.s-1.115

Özer, G., Yücel, R., \& Yılmaz, M. (2003). Kurumsal Kaynak Planlama Sistemlerine Yönelik Kullanıcı Algılarının Analizi [An Analysis of User Perception to Enterprise Resource Planning Systems]. Süleyman Demirel Üniversitesi İktisadi ve İdari Bilimler Fakültesi Dergisi, 8(2), 77-94.

Palvia, S. C., Sharma, R. S., \& Conrath, D. W. (2001). A Socio Technical Fremework for Quality Assessment of Computer Information Systems. Industrial Management \& Data Systems, 101(5), 237-251. 
http://dx.doi.org/10.1108/02635570110394635

Perez, M., Sanchez, A. M., Carnicer, P. L., \& Jimenez, M. J. V. (2004). A Technology Acceptance Model of İnovation Adoption: The Case of Teleworking. European Journal of Innovation Management, 7(4), 280-291. http://dx.doi.org/10.1108/14601060410565038

Petroni, A., \& Rizzi, A. (2001). Antecedents of MRP Adoption in Small and Medium Sized Firms. Benchmarking, 8(2), 144-156. http://dx.doi.org/10.1108/14635770110389852

Poston, R., \& Grabski, S. (2001). Financial Impacts of Enterprise Resource Planning Implementations. International Journal of Accounting Information Sytems, 2, 271-294. http://dx.doi.org/10.1016/S1467-0895(01)00024-0

Ramamurthy, K., \& Premkumar, G. (1995). Determinant and Outcomes of Electronic Data Interchange Diffusion. IEEE Trans. Eng.Management, 42(4), 332-351. http://dx.doi.org/10.1109/17.482083

Rashid, M. A., Hossain, L., \& Patrick, J. D. (2002). Enterprise Resource Planning Solutions and Management. In Nah, F. F. H. (Ed.), The Evolution of ERP Systems: A Historical Perspective (pp. 35-50). Hershey, Amerika Birleşik Devletleri: Idea Group Publishing.

Reck, J. L. (2004). Firm Performance Effects in Relation to The Implementation and Use of Enterprise Resource Planning Systems. Journal of Information Systems, 18(2), 107-110. http://dx.doi.org/10.2308/jis.2004.18.2.107

Sheu, C., Chae, B., \& Yang, C. L. (2004). National Differences and ERP Implementation: Issues and Challenges. Omega, 32, 361-371. http://dx.doi.org/10.1016/j.omega.2004.02.001

Siriginidi, S. R. (2000). Enterprise Resource Planning in Reengineering Business. Business Process Management Journal, 6(5), 376-391. http://dx.doi.org/10.1108/14637150010352390

Stenbeck, J. (1998). Evolving Enterprise. Information Technologies for Manufacturing Competitiveness, 1(2), $1-9$.

Strandholm, K., Kumar, K., \& Subramanian, R. (2004). Examining The Interrelationships Among Perceived Environmental Change, Strategic Response, Managerial Characteristics and Organizational Performance. Journal of Business Research, 57, 58-68. http://dx.doi.org/10.1016/S0148-2963(02)00285-0

Stratman, J. K., \& Roth, A. V. (2002). Enterprise Resource Planning (ERP) Competence Constructs: Two-Stage Multi-Item Scale Development and Validation. Decision Sciences, 33(4), 601-628. http://dx.doi.org/10.1111/j.1540-5915.2002.tb01658.x

Thong, J. Y. L., Yap, C. S., \& Raman, K. S. (1996). Top Management Support, External Expertise and Information Systems Implementation in Small Businesses. Information Systems Research, 7(2), 248-267. http://dx.doi.org/10.1287/isre.7.2.248

Thong, J. Y. L., Yap, C. S., \& Raman, K. S. (1997). Environments for İnformation Systems Implementation in Small Businesses. Journal of Organizational Computing and Electronic Commerce, 7(4), 253-278. http://dx.doi.org/10.1207/s15327744joce0704_1

Thornhill, S. (2006). Knowledge, Innovation and Firm Performance in High and Low Technology Regimes. Journal of Business Venturing, 21, 687-703. http://dx.doi.org/10.1016/j.jbusvent.2005.06.001

Torkzadeh, G., \& Doll, W. J. (1999). The Development of a Tool For Measuring The Perceived Impact of Information Technology on Work. Omega, 27, 327-339. http://dx.doi.org/10.1016/S0305-0483(98)00049-8

Torkzadeh, G., Koufteros, X., \& Doll, W. J. (2005). Confirmatory Factor Analysis and Factorial Invariance of The Impact of Information Technology Instrument. Omega, 33(2), 107-118. http://dx.doi.org/10.1016/j.omega.2004.03.009

Umble, E. J., \& Umble, M. M. (2002). Avoiding ERP Implementation Failure. Industrial Management, 44(1), 25-33.

Wei, C. C., \& Wang, M. J. J. (2004). A Comprehensive Framework for Selecting an ERP System. International Journal of Project Management, 22, 161-169. http://dx.doi.org/10.1016/S0263-7863(02)00064-9

Westerberg, M., Singh, J., \& Hackner, E. (1997). Does The CEO Matter? An Empirical Study of Small Swedish Firms Operating in Turbulent Environments. Scandinavian Journal of Management, 13(3), 251-270. http://dx.doi.org/10.1016/S0956-5221(97)00011-0

Zhang, L., Lee, M. K. O., Zhang, Z., \& Banerjee, P. (2003). Critical Success Factors of Enterprise Resource 
Planning Systems Implementation Success in China. IEEE Computer Society, 36(1), 236-245.

Zviran, M., \& Erlich, Z. (2003). Measuring IS User Satisfaction: Review and Implications. Communications of The Association for Information Systems, 2003(12), 81-103.

\section{Note}

Note 1. According to Baron and Kenny (1986, p.1177), some spesific conditions must be exist for mediation effect. They explain these conditions as follows: "First, the independent variable must affect the mediator in the first equation; second, the independent variable must be shown to affect the dependent variable in the second equation; and third, the mediator must affect the dependent variable in the third equation. If these conditions all hold in the predicted direction, then the effect of the independent variable on the dependent variable must be less in the third equation than in the second." 